\title{
Role of mast cells in cow metritis
}

\author{
Guo-Qing Wang, Jin-Long Hou, \\ Huan-Yu Huang, Chao-Wen Yuan \\ Institute of Biotechnology, \\ Northeast University, Shenyang 110004, China \\ wangguoqing@mail.neu.edu.cn
}

Received: October 16, 2015

Accepted: May 16, 2016

\begin{abstract}
Introduction: Bovine postpartum metritis causes great losses. Mast cell (MC)-released mediators participate in uterine inflammation and immune response, but their role in postpartum metritis in cows has not been reported. This study investigated the effect of endometrial MC on the disorder. Material and Methods: Ten dairy cows, at 6 to 10 days postpartum and with acute purulent metritis made up the experimental group, and 10 comparable healthy cows the control group. Endometrial histamine and IgE levels were determined by ELISA, and the MC particle state and expression of histamine $\mathrm{H}_{1}\left(\mathrm{H}_{1} \mathrm{R}\right)$ and $\mathrm{H}_{2}\left(\mathrm{H}_{2} \mathrm{R}\right) \mathrm{mRNA}$ receptors were examined by transmission electron microscope and real-time quantitative PCR, respectively. Results: Endometrial histamine and IgE levels were significantly higher in the experimental group. In the control group, homogenously distributed size-varied granules were seen in MC cytoplasm of endometrium of lamina propria. In the experimental group however, these showed degranulation with features of reduction. The level of $\mathrm{H}_{1} \mathrm{R}$ mRNA was lower in the experimental group, but that of $\mathrm{H}_{2} \mathrm{R}$ mRNA was higher. Conclusion: The results suggest $\mathrm{MC}$ type I hypersensitivity characteristics during metritis, and histamine provocation of local inflammation. High expression of $\mathrm{H}_{2} \mathrm{R}$ and low expression of $\mathrm{H}_{1} \mathrm{R}$ inhibited the inflammatory response and prevented excessive uterine tissue damage.
\end{abstract}

Keywords: cow, metritis, mast cell, histamine.

\section{Introduction}

Postpartum metritis is one of the most important reproductive disorders in cows, causing great economic losses. Metritis is caused by pathogens identified as facultative pathogenic bacteria $(12,22)$. Many of them commonly exist, however, in cows 10-14 days after delivery (23) and the immune status of a cow's uterus determines the onset of metritis (22). It has been proved that the mast cells (MC) of the uterus regularly change following the reproductive cycle (10). MC regulate proliferation of endometrial blood vessels and secretion of proteins, and control physiological functions of the uterus (21). MC of the uterus release a large number of mediators, such as histamine and TNF- $\alpha$. These mediators collect neutrophil granulocytes to regulate reproduction (18) and also participate in the inflammatory process and immune response. Deng et al. (7) suggested that the number of MC and content of histamine are in proportion to the level of local immunity, and so could be considered signs of the immune status of the uterus. Therefore, MC not only regulate physiological functions of the uterus, but also influence its immunity.

When the IgE made by the sensibiligen crosslinks the FceR1 which binds on the MC membrane, intracellular granules are secreted by MC. This whole process is defined as MC degranulation. Histamine is well known as an important mediator of MC, and it is an autacoid with important regulatory effects on human immune and allergic responses, as well as cell proliferation, vaso-regulation, cellular chemotaxis, and secretory activity (24). Histamine is responsible for biological functions, such as the expression of histamine receptors (mainly $\mathrm{H}_{1} \mathrm{R}, \mathrm{H}_{2} \mathrm{R}, \mathrm{H}_{3} \mathrm{R}$, and $\mathrm{H}_{4} \mathrm{R}$ ) relying on target cells $(8,13)$. Among these receptors, $\mathrm{H}_{1} \mathrm{R}$ and $\mathrm{H}_{2} \mathrm{R}$ are expressed in endometrial cells and immune cells (6). Yamaki et al. (25) suggested that histamine increases the expression of cell adhesion molecules in endothelial cells, such as ICAM-1, VCAM-1, and P-lectin, through $\mathrm{H}_{1} \mathrm{R}$. Furthermore, histamine can also stimulate immunocytes like MC, to produce inflammatory factors, which then activate inflammatory response. But $\mathrm{H}_{2} \mathrm{R}$ could inhibit local mucosal-specific immune 
responses (1). Histamine up-regulates the expression of toll-like receptors (TLR) -2 and -4 , enhances the sensitivity of endometrium to bacteria (16), and plays an important role in regulating mucosal immunity.

MC are important regulators for inflammatory reaction and uterine physiological function, but their role in postpartum metritis in cows has not been reported. Therefore, MC in cow endometrium, endometrial histamine and IgE levels, and the relationship between the histamine and mRNA expression of $\mathrm{H}_{1} \mathrm{R}$ and $\mathrm{H}_{2} \mathrm{R}$ were analysed to investigate the effect of endometrial $\mathrm{MC}$ on postpartum metritis in cows.

\section{Material and Methods}

Animals. Healthy Holstein cows $(\mathrm{n}=10), 3-6$ years of age and at 6 to 10 days postpartum, were selected as a control group. Ten Holstein cows, 3-6 years old, at 6 to 10 days postpartum, and with acute suppurative postpartum metritis diagnosed by clinical symptoms and rectal examination, were selected as an experimental group.

Sample collection. According to the method described by Chapwanya et al. (5), bovine endometrium samples were collected by biopsy. Endometrium tissue pieces were stored in $2.5 \%$ glutaraldehyde $(\mathrm{pH} 7.4)$, either at $4^{\circ} \mathrm{C}$ or at $-70^{\circ} \mathrm{C}$. The state of the uterus was observed after sample collection until the cow became pregnant and no abnormalities were observed.

ELISA. The concentrations of histamine and $\operatorname{IgE}$ were measured using an ELISA kit (R\&D Systems, USA) according to the manufacturer's instructions, with the use of an ELX800 microplate reader (Bio-Tek, USA) at the wavelength of $450 \mathrm{~nm}$. Standard reagents were used to construct a calibration curve. The sample OD value and the calibration curve were used to calculate the product concentration.

Transmission electron microscope (TEM) examination. Endometrium samples were fixed with $2.5 \%$ glutaraldehyde in $0.1 \mathrm{M}$ sodium phosphate buffer (pH 7.2) for $2 \mathrm{~h}$ at $4^{\circ} \mathrm{C}$, and then $1 \mathrm{~mm} \times 2 \mathrm{~mm}$ samples were prepared. The samples were kept in sucrose phosphate buffer for $10 \mathrm{~min}$ three times, post-fixed with $1 \%$ osmic acid for $1 \mathrm{~h}$ at $4^{\circ} \mathrm{C}$, dehydrated by a graded ethanol series, washed with propylene oxide, and then embedded in Epon. Semi-thin sections $(1 \mu \mathrm{m})$ stained with toluidine blue $(\mathrm{pH}$ 8.5) were observed under a microscope and regions with MC were selected.
Ultrathin sections $(0.05 \mu \mathrm{m})$ prepared with an LKB ultratome (LKB-Produkter, Sweden) were preheated with lead citrate or uranyl acetate and lead citrate (double staining) and then examined using a JEM 100-CX electron microscope (Jeol, Japan).

Real-time quantitative PCR (q-PCR). Primers were designed using Primer Premier 5.0 (Premier Biosoft, USA) based on the Bos taurus sequences. Table 1 presents the primer sequences, expected product lengths, and accession numbers in GenBank. Total RNA was extracted from endometrium samples with TRIzol reagent (Invitrogen, USA), and $1 \mu \mathrm{g}$ of total RNA was subjected to reverse transcription to form cDNA with transcriptase according to the manufacturer's instructions (Invitrogen, USA). The mRNA expression levels of $\mathrm{H}_{1} \mathrm{R}, \mathrm{H}_{2} \mathrm{R}$, and $\beta$-actin were quantified by real-time PCR with a LightCycler (Roche Life Sciences, USA) using a commercial kit (TaKaRa, Japan). The values were normalised using $\beta$-actin as an internal standard.

Statistical analysis. The SPSS 13.0 statistics software package (IBM, USA) was used to process the experimental data, and one-way analysis of variance was applied. Data is presented as means \pm SD. $\mathrm{P}<0.05$ were considered significant, and $\mathrm{P}<0.01$ markedly significant.

\section{Results}

Histamine and IgE concentrations. The levels of endometrial histamine and $\mathrm{IgE}$ are shown in Table 2. The histamine and IgE concentrations were significantly higher in the experimental group than in the control group ( $\mathrm{P}<0.01$ and $\mathrm{P}<0.05$ respectively).

MC ultrastructure. In the experimental group (Fig. 1 A), MC granules were distributed unevenly, and the cavities were enlarged and appeared to be vacuolated. In the control group (Fig. $1 \mathrm{~B}$ ), MC granules were of different sizes and were homogeneously distributed. Compared with the control group, MC degranulation increased significantly in the experimental group.

Level of $H_{1} R$ and $H_{2} R$ mRNA expression. The expression level of $\mathrm{H}_{1} \mathrm{R}$ mRNA was significantly lower in the experimental group than in the control group ( $\mathrm{P}<0.05)$, but the level of $\mathrm{H}_{2} \mathrm{R}$ mRNA was higher in the experimental group than in the control group $(\mathrm{P}<0.01)$ (Fig. 2).

Table 1. The primer sequences and PCR product length of the target genes

\begin{tabular}{lll}
\hline Gene/Accession number & Primer sequence & Fragment size (bp) \\
\hline $\mathrm{H}_{1} \mathrm{R}$ & Forward 5'- GTGGGCACTAAGAAACC -3' & \multirow{2}{*}{$191 \mathrm{bp}$} \\
$(\mathrm{BC} 140475)$ & Reverse 5'- TCAAGCGGGAAGCAGTAG -3' & \\
$\mathrm{H}_{2} \mathrm{R}$ & Forward 5'- GTCATTTCCATCACCCTG -3' & $193 \mathrm{bp}$ \\
$(\mathrm{XM}$ 599517.2) & Reverse 5'- TCCTGAAGATGCGGTAGTA -3' & \\
$\beta$-actin & Forward 5'- TCACCAACTGGGACGACA -3' & $206 \mathrm{bp}$ \\
$\left(\mathrm{NM} \_173979.3\right)$ & Reverse 5'- GCATACAGGGACAGCACA -3' & \\
\hline
\end{tabular}


Table 2. Histamine and $\operatorname{IgE}$ concentrations in the endometrium

\begin{tabular}{llll}
\hline Parameters & Control group & Experimental group & P value \\
\hline Histamine, $\mathrm{ng} / \mathrm{mL}$ & $39.204 \pm 4.278$ & $80.305 \pm 4.002$ & $\mathrm{P}<0.01$ \\
$\mathrm{Ig}$ E,$\mu \mathrm{g} / \mathrm{mL}$ & $6.596 \pm 0.202$ & $11.398 \pm 1.342$ & $\mathrm{P}<0.05$ \\
\hline
\end{tabular}
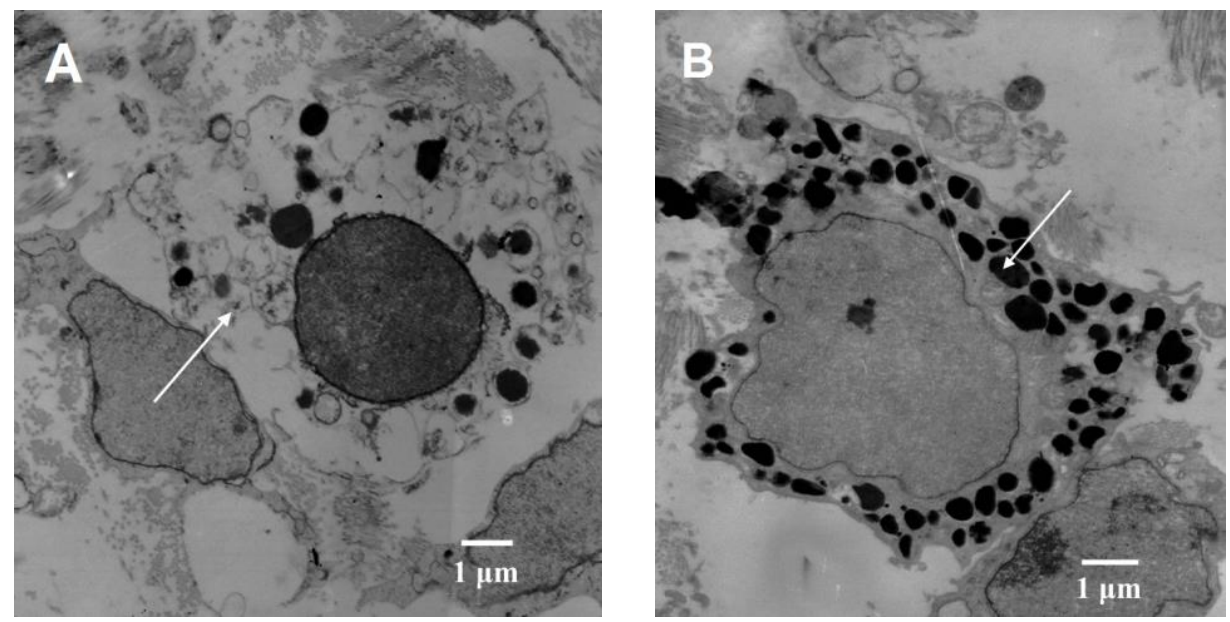

Fig. 1. Ultrastructure of MC endometrial lamina propria. A. - Experimental group; B. - Control group (arrows indicate MC nucleus)

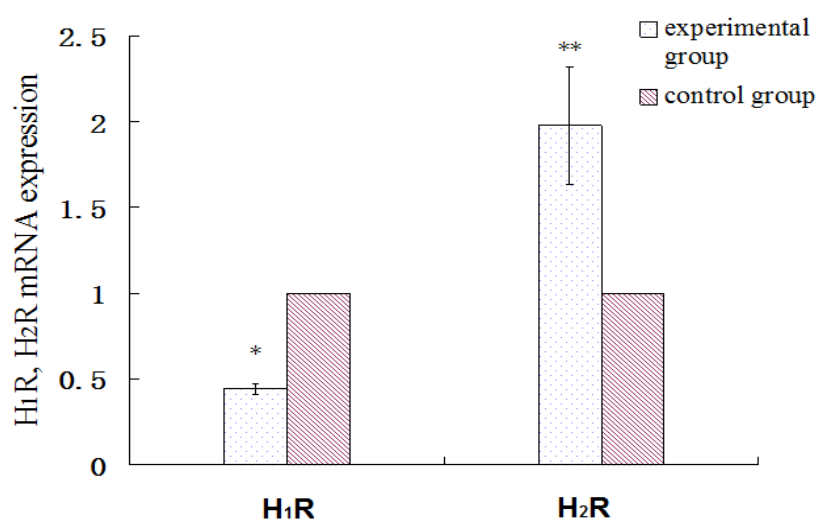

Fig. 2. Expression of $\mathrm{H}_{1} \mathrm{R}$ and $\mathrm{H}_{2} \mathrm{R}$ mRNA by real-time quantitative PCR $* \mathrm{P}<0.05 ; * * \mathrm{P}<0.01$

\section{Discussion}

Mast cells are mainly distributed in the endometrial lamina propria, serving as sentries monitoring bacterial invasion and initiating an immune response against pathogens. Once activated, MC can rapidly release MC mediators like histamine and cell factors (15), which play a regulatory role in immune response and inflammatory reaction. Degranulation is also a sign of activated MC (14). MC degranulation is primarily mediated by IgE, which can make MC sensitive via binding to FceRI on the surface of MC. When the identical antigens enter the body and bind to the $\operatorname{IgE}$ on the surface of MC, MC are activated by crosslinking and their degranulation is promoted (19).

Histamine is the major mediator of MC, which participates in most immune and inflammatory reactions (1). It commonly expresses its functions in many cells and tissues through HR. Histamine can activate nuclear transcription factor $(\mathrm{NF}-\kappa \mathrm{B})$ and influence the expression of inflammatory genes. Besides, it can enhance the secretion of proinflammatory cytokines and chemotactic factors, such as IL-1 $\alpha$, IL-6, IL-8, and others (4), and induce inflammation reactions. Meanwhile inflammatory factors and LPS can also promote the synthesis of histamine (9). Histamine, heparin, tryptase, and cytokine from MC protect cells by stimulating proliferation of fibroblasts, accumulation of extracellular matrix, and fibrosis in some inflammatory reactions (11). Postpartum metritis is caused by conditional pathogens which commonly exist in the environment, and their antigens can sensitise an organism (2). When they invade the uterus en masse after delivery, they cause MC degranulation in the endometrium and promote a local inflammatory reaction. In this paper, MC degranulation was observed, and the expression of the histamine and $\operatorname{IgE}$ was significantly increased in the endometrium. 
The activation of the histamine signalling pathway depends on $\mathrm{H}_{1} \mathrm{R}, \mathrm{H}_{2} \mathrm{R}, \mathrm{H}_{3} \mathrm{R}$, and $\mathrm{H}_{4} \mathrm{R} . \mathrm{H}_{1} \mathrm{R}$ and $\mathrm{H}_{2} \mathrm{R}$ are distributed in the uterine tissue (6). $\mathrm{H}_{1} \mathrm{R}$ can stimulate the immune system to enhance immune response and inflammatory reaction. Tissue damage mediated through histamine is set in process by $\mathrm{H}_{1} \mathrm{R}$, thus $\mathrm{H}_{1} \mathrm{R}$ antagonists can inhibit the secretion of colony-stimulating factor (CSF), IL-6, and IL-8. They are also able to inhibit the $\mathrm{Ca}^{2+}$-dependent NF- $\kappa \mathrm{B}$ signalling pathway which is mediated through histamine (17). The increased histamine can cause tissue damage in the inflammatory reaction, and $\mathrm{H}_{1} \mathrm{R}$ antagonists can suppress the effects of histamine (20). Histamine can inhibit the activation of inflammatory cells, degranulation, formation of superoxide, and chemotaxis through $\mathrm{H}_{2} \mathrm{R}$, which regulates inflammation responses by negative feedback. It can also downregulate NF- $\mathrm{KB}$ and inhibit the inflammation reaction (3). In this research, endometrial $\mathrm{H}_{2} \mathrm{R}$ mRNA and $\mathrm{H}_{1} \mathrm{R}$ mRNA from cows suffering from metritis were expressed. The results showed that the level of $\mathrm{H}_{1} \mathrm{R}$ mRNA was lower in the experimental group than in the control group $(\mathrm{P}<0.05)$, but the level of $\mathrm{H}_{2} \mathrm{R}$ mRNA was higher $(\mathrm{P}<0.01)$. The results suggested that the expression of $\mathrm{H}_{1} \mathrm{R}$ and $\mathrm{H}_{2} \mathrm{R}$ mRNA was unbalanced. The lower expression of $\mathrm{H}_{1} \mathrm{R}$ and higher expression of $\mathrm{H}_{2} \mathrm{R}$ had a protective effect on the tissue damage caused by excessive inflammatory responses.

Conflict of Interests Statement: The authors declare no conflict of interests regarding the publication of this article.

Financial Disclosure Statement: This work was financed by the Natural Science Foundation of China (No.31272615), and Fundamental Research Funds for the Central Universities (No. N130420001)

Statement of Animal Rights: The research was in compliance with Chinese animal welfare regulations and approved by the Local Ethics Committee for Animal Experimentation.

\section{Reference}

1. Akdis C.A., Blaser K.: Histamine in the immune regulation of allergic inflammation. J Allergy Clin Immunol 2003, 112, 15-22.

2. Azawi O.I.: Postpartum uterine infection in cattle. Anim Reprod Sci 2008, 105, 187-208.

3. Bakker R.A., Schoonus S.B., Smit M.J., Timmerman H., Leurs R.: Histamine H1-receptor activation of nuclear factor-kB: roles for $\mathrm{G} \beta \gamma$ - and $\mathrm{G} \alpha_{\mathrm{q} / 11}-$ subunits in constitutive and agonist-mediated signaling. Mol Pharmacol 2001, 60, 1133-1142.

4. Bayram H., Devalia J.L., Khair O.A., Abdelaziz M.M., Sapsford R.J., Czarlewski W., Campbell A.M., Bousquet J., Davies R.J.: Effect of loratadine on nitrogen dioxide-induced changes in electrical resistance and release of inflammatory mediators from cultured human bronchial epithelial cells. J Allergy Clin Immunol 1999, 104, 93-99.
5. Chapwanya A., Meade K.G., Narciandi F., Stanley P., Mee J.F., Doherty M.L., Callanan J.J.: Endometrial biopsy: a valuable clinical and research tool in bovine reproduction. Theriogenology 2010, 73, 988-994.

6. Cruz M.A., Gonzalez C., Sepulveda W.H., Rudolph M.I.: Effect of histamine on human placental chorionic veins: interaction with serotonin. Pharmacology 1991, 42, 86-90.

7. Deng Z.P., Liu Y.W., Zhou Z.X.: Quantitative studies of mast cells and histamine in the endometrium of cow and sheep. China Vet Sci 1994, 1, 50-55

8. De Backer M.D., Loonen I., Verhasselt P., Neefs J.M., Luyten W.H.: Structure of the human $\mathrm{H} 1$ receptor gene. Biochem J 1998, 335, 663-670.

9. Dy M., Arnould A., Lemoine F.M., Machavoine F., Ziltener H., Schneider E.: Hematopoietic progenitors and interleukin-3dependent cell lines synthesize histamine in response to calcium ionophore. Blood 1996, 87, 3161-3169.

10. Eren U., Asti R.N., Kurtdede N., Sandikci M., Sur E.: The histological and histochemical properties of the mast cells and the mast cell heterogeneity in the cow uterus. Turk J Vet Anim Sci 1999, 23, 193-201.

11. Gailit J., Marchese M.J., Kew R.R., Gruber B.L.: The differentiation and function of myofibroblasts is regulated by mast cell mediators. J Invest Dermatol 2001, 117, 1113-1119.

12. Giuliodori M.J., Magnasco R.P., Becu-Villalobos D., LacauMengido I.M., Risco C.A., de la Sota R.L.: Metritis in dairy cows: risk factors and reproductive performance. J Dairy Sci 2013, 96 , 3621-3631.

13. Grantz I., Munzert G., Tashiro T., Schaffer M., Wang L., Del Valle J., Yamada T.: Molecular cloning of the human H2 recptor. Biochem Biophys Res Commun 1991, 178, 1386-1392.

14. Kawakami T., Galli S.J.: Regulation of mast-cell and basophil function and survival by IgE. Nat Rev Immunol 2002, 2, 773-786.

15. Kobayashi H., Ishizuka T., Okayama Y.: Human mast cells and basophils as sources of cytokines. Clin Exp Allergy 2000, 30, 1205-1212.

16. Kobayashi M., Yoshiki R., Sakabe J., Kabashima K., Nakamura M., Tokura Y.: Expression of toll-like receptor 2, NOD2 and dectin-1 and stimulatory effects of their ligands and histamine in normal human keratinocytes. Br J Dermatol 2009, 160, 297-304.

17. Matsubara M., Tamura T., Ohmori K., Hasegawa K.: Histamine $\mathrm{H} 1$ receptor antagonist blocks histamine-induced proinflammatory cytokine production through inhibition of $\mathrm{Ca}^{2+}$-dependent protein kinase C, Raf /MEK/ERK and IKK/I kappa B/NF-kappa B signal cascades. Biochem Pharmacol 2005, 69, 433-449.

18. Mekori Y.A., Metcalfe D.D.: Mast cells in innate immunity. Immunol Rev 2000, 173, 131-140.

19. Metzger H.: The high affinity receptor for IgE, Fcepsilon RI. Novartis Found Symp 2004, 257, 51-59.

20. Neumann D., Schneider E.H., Seifert R.: Analysis of histamine receptor knockout mice in models of inflammation. $\mathrm{J}$ Pharmacol Exp Ther 2014, 348, 2-11.

21. Rudolph M.I., Rojas I.G., Penissi A.B.: Uterine mast cells: a new hypothesis to understand how we are born. Biocell 2004, 28, 1-11.

22. Sheldon I.M., Cronin J., Goetze L., Donofrio G., Schuberth H.J.: Defining postpartum uterine disease and the mechanisms of infection and immunity in the female reproductive tract in cattle. Biol Reprod 2009, 81, 1025-1032

23. Sheldon I.M., Dobson H.: Postpartum uterine health in cattle. Anim Reprod Sci 2004, 82/83, 295-306.

24. Wang L.D., Hoeltzel M., Butler K., Hare B., Todisco A., Wang M., Del Valle J.: Activation of the human histamine H2 receptors is linked to cell proliferation and c-fof gene transcription. Am J Physiol 1997, 273, 2037-2045.

25. Yamaki K., Thorlacius H., Xie X., Lindbom L., Hedqvist P., Raud J.: Characteristics of histamine induced leukocyte rolling in the undisturbed micro circulation of the rat mesentery. $\mathrm{Br} \mathrm{J}$ Pharmacol 1998, 123, 390-399. 